\title{
LAVA CAVES OF THE REPUBLIC OF MAURITIUS, INDIAN OCEAN
}

\author{
Gregory J. Middleton*
}

\begin{abstract}
In their Underground Atlas, MIDDLETON \& WALTHAM (1986) dismissed Mauritius as: "very old volcanic islands with no speleological interest". Recent investigations indicate this judgement is inaccurate; there are over 50 significant caves, including lava tube caves up to $687 \mathrm{~m}$ long (one $665 \mathrm{~m}$ long was surveyed as early as 1769) and $35 \mathrm{~m}$ wide. Plaine des Roches contains the most extensive system of lava tube caves with underground drainage rising at the seashore.

Notable fauna includes an insectivorous bat and a cave swiftlet (Collocalia francica), the nests of which are unfortunately prized for "soup". The caves are generally not valued by the people and are frequently used for rubbish disposal or filled in for agricultural development.
\end{abstract}

Keywords: vulcanospeleology, lava tubes, Mauritius

\section{RÉSUMÉ}

Bien que les îles Maurice ne soient pas connues pour leur intéret spéléologique, de récentes recherches indiquent qu'il y a plus de cinquante cavernes importantes, comprenant des tunnels de lave allant jusqu'à de $687 \mathrm{~m}$ de long et $35 \mathrm{~m}$ de large, l'un d'entre eux, de $665 \mathrm{~m}$ de long a été découvert dès 1769 .

La Plaine des Roches contient le système le plus étendu de tunnels de lave avec un écoulement souterrain qui s'élève au niveau du rivage. La faune importante de ces caves comprend de chauves-souris insectivores et de petites hirondelles (Collocalia francica), les nids desquelles sont malheureusement recherchés pour soupes de gourmets. Les caves ne sont généralement pas appréciées par les habitants qui trop fréquemment s'ent servent comme dépôts d'ordures ou d'entrepôts agricoles.

\section{LOCATION AND GEOLOGY}

The Republic of Mauritius is comprised of two main islands in the southern Indian Ocean, the main one of $1,860 \mathrm{sq} \mathrm{km}$, about $850 \mathrm{~km}$ east of Madagascar, and Rodrigues, $110 \mathrm{sq} \mathrm{km}, 560 \mathrm{~km}$ further east.

The main island is almost entirely volcanic, having originated about 13 million years ago in seabed eruptions which took until about 8 million years ago to reach the ocean's surface. The island's spectacular mountain chains and peaks are remnants of a large shield volcano, the centre of which subsided 5.5 million years ago to form the Mauritian caldera. The rest of the island was fashioned by suites of lavas (Hawaiian flows) emitted from 23 smaller, more recent volcanic structures. Lava flows have occurred as recently as 26,000 years ago in the Plaine des Roches area in the north-east (ANTOINE 1983). There are some limited exposures of calcareous aeolianite on the coasts of both islands and it comprises some small offshore islets. Karst caves are best developed on Rodrigues.

\footnotetext{
* Member, IUS Commission on Volcanic Cave, Sydney Speleological Society, Southern Tasmanian Caverneers, P.O. Box 269, Sandy Bay, Tas. 7006 Australia.
} 


\section{THE LAVA TUBE CAVES}

Lava tube caves occur throughout the main island of Mauritius. Commonly they are the result of rapidly flowing basic (low silica) lavas cooling on the surface and forming a crust over the molten rock below. If the flow is cut off at its source and the lava continues to flow it can leave behind a void, the inner surfaces of which may contain a record of events during the cave's formation. Access to the tubes is generally only made possible by the eventual collapse of part of the roof.

These caves tended to form where conditions were optimal: small, non-explosive eruptions of basic lavas onto gently-sloping surfaces. By noting the orientation and extent of lava tubes it is possible to infer the sources of the relevant flows. Most lava tube caves are found in recent flows as these have had the least time to collapse and as later flows tend to obliterate features beneath them.

The principal localities in Mauritius where lava caves occur (Fig. 1, Table 1) are Plaine des Roches and Nouvelle Decouverte (originating from the Bar le Duc-l'Escalier volcanic system), Vacoas-Palma (Curepipe Point-Trou aux Cerfs-Verdun volcanic structures) and Mont Blanc-Surinam (Bassin Blanc volcanic system) (SADDUL 1995). In the south there is a scatter of small caves in the area extending from Savannah to Plaine Magnien and there is a single, isolated cave in the north at Réunion Maurel.

For convenience the main island has been divided into six regions and within these caves have been grouped into somewhat arbitrary 'cave areas', shown (in bold) on Fig. 1.

Table 1 - Documented lava caves by Region and Area

\begin{tabular}{|llrr|}
\hline Region & \multicolumn{1}{c}{ Area } & $\begin{array}{r}\text { No. of } \\
\text { caves }\end{array}$ & \multicolumn{1}{c|}{$\begin{array}{c}\text { Length } \\
(\mathbf{m})\end{array}$} \\
\hline North-West & Mapou & 1 & 225 \\
North-East & Plaine des Roches & 16 & 2,500 \\
Central West & Plaine St Pierre & 6 & 920 \\
& Plaine Wilhems & 9 & 1,752 \\
Central East & Nouvelle Decouverte & 11 & 1,535 \\
& Trou D'Eau Douce & 2 & 35 \\
South-West & Chamarel Falls & 6 & 110 \\
& Mont Blanc & 6 & 755 \\
South-East & Plaine Magnien & 1 & 85 \\
& Savannah & 3 & 205 \\
\hline
\end{tabular}

The greatest concentration of caves occurs at Plaine des Roches. This is a flat to undulating area, comprised of probably the most recent lava flows on the island, derived from the Bar le Duc-L'Escalier volcanic system and partly from the Mont Pilon volcano (SADDUL 1995, p. 136). The author has documented some 29 cave entrances in this area and 16 discrete caves. The largest of these was surveyed by BILLON et al. (1991) at $520 \mathrm{~m}$. It is a consistently large tube, 10 to $15 \mathrm{~m}$ wide and averaging about 10 $\mathrm{m}$ high. It contains one of the largest bat colonies in Mauritius, estimated at different times at from 10,000 individuals to 10 times that number. It also contains a small but important swiftlet colony of around 50 birds. Nine other lava tubes in the area exceed $100 \mathrm{~m}$ in length. A number of the Plaine des Roches caves contain water and, although no tracing has been done, it is believed that the water bodies are interconnected and that 


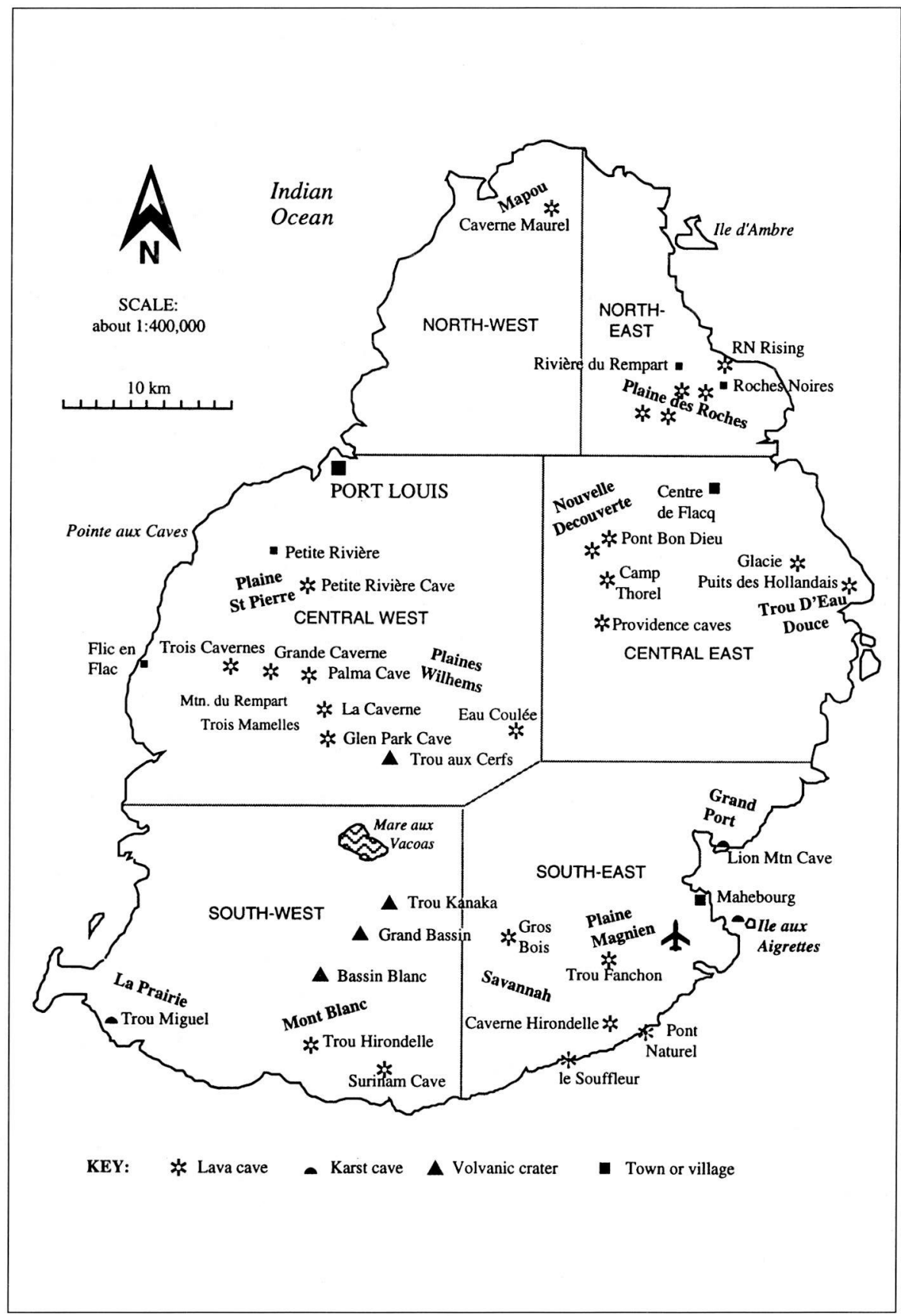

Fig. 1 - Location of the principle caves of the main island of Mauritius showing unofficial cave areas and region. 
the whole system rises at an inlet on the coast. The rising was noted by CLARK (1859) and again by HAIG (1895) who suggested that the inlet was itself a collapsed cave.

Further south on the east coast, near Trou D'Eau Douce, lies the interesting Puits des Hollandais ('Dutch Well'), a water filled circular hole over $10 \mathrm{~m}$ in diameter and around $28 \mathrm{~m}$ deep. The hole opens out with increasing depth attaining a diameter of over $40 \mathrm{~m}$ at the bottom (MIDDLETON, 1996a).

Inland from Plaine des Roches, but probably derived from lava from the same source, lie the $35 \mathrm{~m}$ wide Pont Bon Dieu and the nearby colourful Pont Bon Dieu Jardin Cave which approaches $400 \mathrm{~m}$ in length. Both are biologically significant and the main arch has been provided with improved tourist access. In the same vicinity lies Camp Thorel Cave, the longest lava cave $(687 \mathrm{~m})$ and the most complex, with up to five parallel passages (BILLON et al. 1991).

The isolated Petite Rivière Cave on Plaine St Pierre is $665 \mathrm{~m}$ long (BILLON et al. 1991; MIDDLETON 1994a) and was the first to be documented, having been mentioned in a letter written by Bernardin de Saint-Pierre in 1769 and published in 1773 (MIDDLETON, 1995, 1996c). Saint-Pierre included a table setting out the lengths, width and heights of each section of the cave prepared by one Marquis d'Albergati in 1769. These details would have been sufficient to draw up a plan of the cave but unfortunately there is no evidence that this was done.

Petite Rivière Cave is also the Mauritian cave most frequently referred to in the literature, notably by GRANT (1801), BAILLY (1802, quoted by MILBERT 1812), PIKE (1873) and HAIG (1895). It also has the distinction of being the first Mauritian cave to feature in a published illustration (Fig. 2). Although the correspondence with reality is slight, there can be little doubt that de Sainson's drawing of 1828 , published in D'URVILLE (1830) is meant to be the Petite Rivière Cave.

South of Petite Rivière on Plaine St Pierre lie the Trois Cavernes, caves of considerable historical interest because FLINDERS (1814) recorded that the largest was used as a refuge by escaped slaves in the 1770 s, over fifty having been caught there on one occasion by police. He recorded that "little oblong enclosures, formed with small stones by the sides of the cavern, once the sleeping places of the wretches, also [still] existed, nearly in the state they had been left" (FLINDERS 1814). MIDDLETON $(1995,1996 \mathrm{c})$ believes some of these stone arrangements persist to this day. Nearby, at Xavier on the Black River road, in January 1997, a bulldozer driver broke into a lava 'blister' or hol-

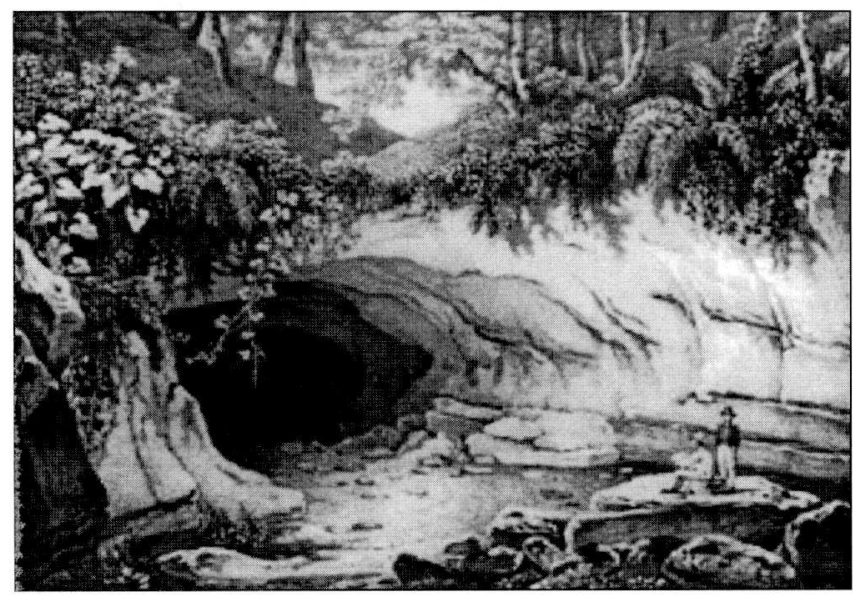

Fig. 2 - "Une Grotte du quartier de la grande rivière (Ile Maurice)" by de Sainson first published illustration of a Mauritian Cave. 
low tumulus, about $5 \mathrm{~m}$ high and $12 \mathrm{~m}$ in diameter with a crust about $1.5 \mathrm{~m}$ thick. This became an instant, if short-term, tourist attraction.

There are a few caves in the Plaines Wilhems area near the centre of the island, notably Glen Park Cave $(440 \mathrm{~m})$ and Palma Cave $(210 \mathrm{~m})$ and recently discovered La Marie Cave $(195 \mathrm{~m})$. The first frequently contains a significant stream, the second is of considerable biological importance and the third appears to flood completely at times of heavy rain. A cave at La Caverne has clearly been known for a long time as it gave its name to the locality; it was modified with concrete in the past for the storing of cheese and butter.

Of the caves in the south, probably associated with the Bassin Blanc volcano, Trou Hirondelle, $442 \mathrm{~m}$ long and containing a significant swiftlet colony, is worthy of mention (MIDDLETON 1994b), as is Surinam Cave which contains the largest known swiftlet colony (650 individuals in August 1996 - Hauchler, pers. comm.) and a unique sudden drop of about $10 \mathrm{~m}$.

\section{CAVE FAUNA}

The most obvious element of the cave fauna is the cave swiftlet, Collocalia franci$c a$. This bird, which navigates underground using audible echolocation 'clicks', nests in suitable caves all over the island and was once very numerous (CHEKE 1987). It is now threatened by sealing of caves and by thefts of its nests, apparently for making 'birds nest soup'. Populations in particular caves have dropped from 'thousands' to rarely more than a hundred. They also occur in Réunion, which is the western limit of the genus, but not on Rodrigues.

Another cave-dwelling vertebrate is the free-tailed bat, Tadarida acetabulosus. Very large colonies occur in two caves in the Plaine des Roches cave area but elsewhere colonies seldom number 2,000. A second species, the tomb bat, Taphozous mauritianus, is not known to inhabit Mauritian caves. Neither species occurs in Rodrigues but both are found in Madagascar and Africa.

Egg scars on the roofs of caves at Roches Noires and Plaine St Pierre indicate that these provided suitable sites for Gunthers gecko, Phelsuma guentheri, to attach its eggs. These are presumed to be very old as the species has been extinct on the mainland for about 200 years.

The shells of many species of land snails are regularly found at cave entrances and under daylight holes. Subfossil shells of Tropidophora carinata (extinct since the 1880s) are common in at least two caves at Plaine des Roches and Pont Bon Dieu. The fact that some still had their opercula in place indicates they died in situ and were not washed into the cave (O. Griffiths, pers. comm.).

Little has been published on the invertebrate fauna of Mauritian caves, but thanks to STRINATI (in press), Mauritius will soon be included in Encyclopaedia Biospeologica II. Strinati has collected at least two new species, an endemic thysanuran (MENDES 1996) and an amphipod (Stock 1997).

\section{THREATS TO THE CAVES}

Most Mauritian caves have been damaged or are under some form of threat. An unknown number have had their entrances filled in the development of sugarcane plantations. This practice still continues, as does the widespread dumping of industrial and 
household waste into caves. At Palma a cave has been sealed by the construction of an underground temple.

Although water from caves is sometimes used for irrigation and domestic purposes, there are places where domestic waste, including sewage, discharges directly into the ground. There appears to be no realisation that the aquifer is at a shallow depth and that very limited purification takes place where there is conduit flow.

It is not unusual for local youths to burn tyres in the lava tube caves of Mauritius, with disastrous results. The worst case is at Caverne Maurel where most of the cave's surface is covered with a deposit of carbon. In at least one cave "black magic" is still being practiced; in the process material is burned on a stone "altar".

The numbers of cave swiftlets have declined steadily over the years and their nests are still taken indiscriminately despite the fact that this is illegal. Recent reports (Hauchler, pers. comm.) indicate this practice may be declining.

The only lava caves with any measure of protection are:

Pont Bon Dieu where the Ministry of Environment has built a fence to prevent rubbish dumping and local youth groups have tidied the access pit;

Palma Cave where the Ministry has, with the concurrence of the owner, built a fence around the entrance to try to prevent removal of swiftlet nests (unfortunately the fence has been cut and the padlock of the gate broken open); and

Petite Rivière Cave where the Medine Sugar estate has built a substantial grille across the entrance to try to protect the swiftlets (unfortunately the gate, which was regularly broken open, was demolished in August 1996 with explosive).

Appreciation of the country's cave resources is coming only slowly and belatedly to Mauritius. It now seems likely that a project to fully document, assess and conserve at least a representative sample of Mauritian caves will be undertaken.

\section{ACKNOWLEDGMENTS}

Dr Trevor Shaw provided many of the historical references; Clement Moutou, Jörg Hauchler, Mario Allet and Paul Moolee made invaluable contributions to the field work; Owen Griffiths and Pierre Strinati contributed the de Sainson illustration and biological details; Carl Jones advised in relation to vertebrates; thanks to Prem Saddul for geological and geomorphological details and for constructive criticism; thanks to Jörg Hauchler for constructive criticism and updating; Yousoof Mungroo, Director of the National Parks \& Conservation Service, made much of the work possible.

\section{REFERENCES}

ANTOINE, R. 1983 La derniere coulée de laves à l'île Maurice. Revue Agricole et Sucriere, 62(2):91-92

BILLON, F., P. CHOJNACKI, C. BILLON, AND G. ROUSSEAU. 1991. Explorations souterraines à l'île Maurice Spéléo-Club Nivernibou: Decize, France 46 pp.

CHEKE, A.S. 1987 The ecology of the smaller land-birds of Mauritius [in] Diamond, A.W. (Ed.) Studies of Mascarene island birds Cambridge Univ. Press: UK pp. 151-207

CLARK, G. 1859 A ramble round Mauritius with some excursions to the interior of that island ... [in] Palmer \& Bradshaw The Mauritius register: historical, official and commercial pp. i-cxxxii Port Louis: L. Channell. Reprinted in La Revue Agricole, 24(1):34-51; (2):96-114 (1945)

D'URVILLE, J.S.C. DUMONT, LE COMTE 1830 Voyage de la corvette l'Astrolabe. Exécuté par ordre du Roi, pendant les années 1826-29 sous le commandement de M. J. Dumont D'Urville. J. Tastu: Paris. "Atlas", vol. 2, pl. 243. 
FLINDERS, M. 1814 A voyage to Terra Australis undertaken for the purpose of completing the discovery of that vast country G. \& A. Nicol: London 2 vols.

GRANT, C. 1801. The history of Mauritius or the Isle of France and the neighbouring islands ... composed principally from the papers and memoirs of Baron Grant, ... by his son W. Bulmer \& Co.: London

HAIG, H. DE HAGA 1895 Physical features and geology of Mauritius. Quart. J. Geol. Soc. London, 51(Aug. 1895):463-471.

MENDES, L.F. 1996 Further data on the Nicolettidae (Zygentoma), with a description of a new species from Mauritius. Revue Suisse de Zoologie, 103(3):749-756.

MIDDLETON, G. 1994a Rambles under Mauritius \#1 - Petite Rivière. J. Syd. Speleol. Soc., 38(8):131-133.

MIDDLETON, G. 1994b Rambles under Mauritius \#2 - Chemin Grenier. J. Syd. Speleol. Soc., 38(9):149-150.

MIDDLETON, G. 1995 Early accounts of caves in Mauritius. (Presented at Second Australian Seminar on Spelean History, Sydney, July 1994) Helictite, 33(1):5-18.

MIDDLETON, G. 1996a Rambles under Mauritius \#6 - Puits des Hollandais. J. Syd. Speleol. Soc., 40(1):3-5.

MIDDLETON, G. 1996b Rambles under Mauritius \#7 - Plaine Corail, Rodrigues. J. Syd. Speleol. Soc., 40(6):83-94.

MIDDLETON, G. 1996c Early accounts of caves in Mauritius. Proc. Roy. Soc. Arts \& Sci., Mauritius, VI:49-87

MIDDLETON, J. and T. WALTHAM. 1986 The Underground Atlas Robert Hale: London. p. 134

MILBERT, J. 1812 Voyage pittoresque à l'isle-de-France, au Cap de Bonne Espérance et à l'Isle de Ténériffe Nepveu: Paris Vol. 1 pp. 358-360 and Vol. 2 pp. 102-104.

PIKE, N. 1873 Sub-tropical rambles in the land of Aphenapteryx: personal experiences, adventures \& wanderings in and around the island of Mauritius Sampson Low, Marston, Low \& Searle: London

[SAINT-PIERRE, B. DE] 1773 Voyage à l'Isle de France, à l'Isle de Bourbon, au Cap de Bonne Espérance par un officier du Roi Amsterdam, Vol. 1, pp. 249-254

SADDUL, P. 1995 Mauritius: A Geomorphological Analysis. Mahatma Gandhi Institute: Moka 340 pp.

STOCK, J. H. 1997 A new species of Brevitalitrus (Crustaces, Amphipoda, Talitridae) from Mauritius - first record of the genus from the Indian Ocean. Revue Suisse de Zoologie, 104(1):3-11

STRINATI, P. in press Ile Maurice [in] Encyclopaedia Biospeologica II. 